
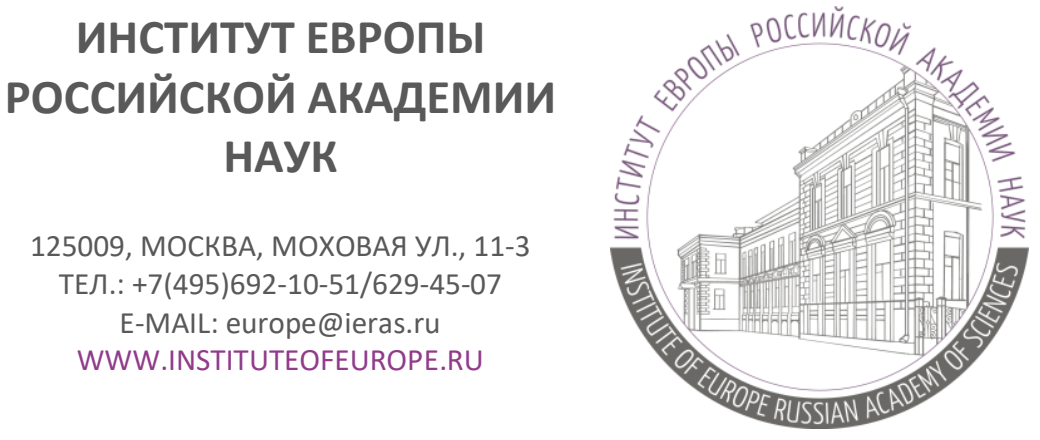

125009, MOSCOW, MOKHOVAYA STR., 11-3

TEL.: +7(495)692-10-51/629-45-07

E-MAIL: europe-ins@mail.ru WWW.INSTITUTEOFEUROPE.RU

\author{
Аналитическая записка №15, 2020 (№198) ${ }^{1}$
}

\title{
Популизм и корона: как пандемия влияет на правопопулистские партии Европы?
}

\section{Петр Викторович Осколков}

кандидат политических наук, старший научный сотрудник Отдела исследований европейской интеграции Института Европы РАН

\begin{abstract}
Аннотация. Пандемия COVID-19 - это серьёзный вызов не только для здоровья жстелей ЕC и экономической сферы, но и для политического поля. Различные политические силы вырабатывают собственные стратегии поведения в условиях пандемии, успех которых во многом будет зависеть от дальнейшей кризисной динамики. Автор анализирует уже имеющийся эффект и возможные последствия распространения в мире коронавируса для правопопулистских партий Европейского союза: может ли популизм извлечь выгоду из сложивщейся ситуации, пройти «тест на прочность» в кризисных условиях и реабилитироваться до очередных национальных выборов.
\end{abstract}

Ключевые слова: популизм, коронавирус, национализм, биополитика, миграция.

Популизм (правый и левый) - явление, существовавшее в политике всегда. Но пристальное внимание на него обратили не так давно (преимущественно в отношении европейской и американской политики). В поле зрения политической науки он находится примерно последние 50 лет (с публикации хрестоматийного сборника под

\footnotetext{
${ }^{1}$ DOI: http://doi.org/10.15211/analytics 152020
} 
редакцией Э. Геллнера и Г. Ионеску²). Особое внимание в последние 10 лет уделяется правому популизму: интерес к нему подогревался громкими предвыборными кампаниями Г. Вилдерса, М. Ле Пен и М. Сальвини, а также победами на выборах Д. Трампа и Ж. Болсонару.

Что же такое популизм? В самом общем виде его можно определить как политическую стратегию, основанную на обращении к народу, антиэлитизме, предпочтении прямой демократии, видении «народа» как однородного организма. Если мы говорим о правом популизме, он также комбинируется с национализмом (или же нативизмом противопоставлением условных «своих» условным «чужим»). Очевидно, что популизм стремится предлагать демонстративно упрощённые решения сложных политических и социально-экономических проблем, а также не обходит стороной ни один «горячий» вопрос публичного дискурса, потому что только на таких, насущных и широко обсуждаемых, вопросах он и может привлечь к себе внимание избирателей. Как же европейский правый популизм отреагировал на заставивший всю планету застыть в карантинном ожидании коронавирус COVID-19?

Безусловно, пока рано подводить итоги, пандемия ещё не преодолена, а для правопопулистских партий ещё не настал очередной момент истины - первые после кризиса выборы в национальные парламенты. Однако два аспекта уже очевидны.

Во-первых, предсказуемо, популистские партии попытались извлечь тактические выгоды из возникновения новой насущной проблемы. Закрытие границ, ограничение иммиграции, концентрация полномочий в рамках национального государства - не к этому ли они призывали все эти годы? Неэффективность (якобы имеющая место) наднациональной системы управления в ЕС - не об этом ли они говорили в каждом публичном заявлении?

Казалось бы, основные их программные пункты подтвердились сами собой. Как минимум, актуализируется правопопулистская повестка в сфере биополитики: именно ей, то есть отношению государства к телесной жизни человека, по сути, посвящена в той или иной степени популистская риторика. Свобода передвижения, этические аспекты прав ЛГБТ, абортов и эвтаназии давно находятся в фокусе популистских идеологов, а тема эпидемии и пандемии неизбежно превращается в торжество биополитики. Как писал Дж. Агамбен, «за долгим антагонистическим процессом, ведущим к признанию формальных прав и свобод, вновь обнаруживается тело священного человека с его двойственным суверенитетом, его жизнью, которую нельзя принести в жертву, но, тем не менее, можно отнять» ${ }^{3}$. Отношение к человеческой жизни, к человеческому телу во время массового распространения карантина, «социальной дистанции», обязательного ношения средств защиты невольно подкрепляет и обосновывает - хотя бы и на подсознательном уровне биополитическую риторику правых популистов, националистов и радикальных консерваторов.

\footnotetext{
${ }^{2}$ Populism: Its Meaning and National Characteristics. Ed. by Gh. Ionescu and E. Gellner. New York: Macmillan, 1969. $263 \mathrm{p}$.

${ }_{3}^{3}$ Агамбен Дж. Ното sacer. Суверенная власть и голая жизнь. М.: Европа, 2011. С. 17.
} 
При этом популисты, только стремящиеся к власти (оппозиция), и уже пришедшие к ней, реагируют на коронакризис по-разному.

Оппозиционные правопопулистские партии привычно критикуют действующие правительства - на этот раз за бездействие или позднее реагирование. Марин Ле Пен раскритиковала «религию открытых границ», лидер фракции «Альтернативы для Германии» в Бундестаге Алиса Вайдель высказалась о «догме открытых границ». Когда правительство Нидерландов в начале апреля отказалось вводить обязательный lockdown в стране, оставив это на усмотрение отдельных компаний, с требованиями обязательного карантина и жёсткой критикой правительства выступили именно правопопулистские «Форум за демократию» Тьерри Бодэ и «Партия свободы» Геерта Вилдерса. Наибольшие шансы обратить ситуацию в свою пользу - у лидера итальянской «Лиги» Маттео Сальвини, уже полгода пытающегося спровоцировать отставку правительства Джузеппе Конте, которое он был вынужден покинуть ${ }^{4}$. Впрочем, Сальвини изначально оказался плохо осведомлён: резкий рост заражения коронавирусом он, по традиции, приписал иммигрантам из Северной Африки, прибывающим в Италию по морю.

Правопопулистские партии, уже находящиеся у власти, стремятся предельно расширить свои полномочия. Так поступил венгерский премьер-министр Виктор Орбан, который с 30 марта ввёл в стране чрезвычайное положение, присвоил себе особые законодательные полномочия («указное право») и предложил ввести уголовную ответственность за распространение ложных сведений - вплоть до 5 лет тюремного заключения. Не исключено, что последняя мера может быть применена для того, чтобы существенно ограничить свободу прессы в стране.

Во-вторых, оппозиционные и правительственные правопопулистские партии пока не прошли проверку на прочность в кризисной ситуации. С одной стороны, сложно сказать, что её прошли и партии мейнстрима, не относящиеся к популистам - в возникшей панике мало кто из партийных деятелей смог показать себя спасителем нации. С другой, непопулистские партии мейнстрима и не нуждаются в каждодневном подтверждении своей правоты, их стратегия не строится на постоянном оспаривании действий условной элиты и предложении альтернативных решений. А популистские политические силы как раз на этом и основывают свои претензии на вхождение во власть.

Одна из наиболее распространённых точек зрения по поводу эффективности популистских стратегий партий заключается в том, что, получив реальную возможность отправления публичной власти, они с ней не справляются - о чём говорит пример «Истинных финнов» или «Австрийской партии свободы». Либо же, придя к власти, они постепенно преобразуют всю политическую систему в антидемократическом направлении: это демонстрируют примеры польской «Право и Справедливость» и венгерского «ФИДЕС».

\footnotetext{
4 Дунаев А. Коронавирус для ультраправых. Чем обернется эпидемия в Италии. Московский Центр Карнеги, 28.02.2020. URL: https://carnegie.ru/commentary/81175 (дата обращения: 09.04.2020).
} 
Получив шанс предложить сейчас альтернативную повестку, большинство популистов не справились с неожиданно свалившейся на них ответственностью. Бельгийский «Фламандский интерес», нидерландский «Форум за демократию», французское «Национальное объединение» и другие игроки лишь следуют указаниям и нормам, выработанным мейнстримом. Не забывая при этом о своих «традиционных» пунктах к примеру, лидер «Фламандского интереса» Том Ван Грикен написал 4 апреля в твиттере: «Всё остановилось, кроме мусульманского террора и массовой миграции... Двое убитых и семь раненых в результате ножевой атаки во Франции, которую совершил беженец из Судана». Действительно, есть вещи, которые не прекращаются даже во время пандемии, но в нынешних условиях антиисламские призывы вряд ли остаются актуальными.

Как верно отметила британский политолог М. Пальярелло, «если раньше врагом был мигрант, то теперь враг - это мигрант, у которого коронавирус» ${ }^{5}$. Популистские партии могут исходить из того, что пандемия прекратится, и приоритеты избирателей вернутся на круги своя, но сейчас им стоило бы больше внимания уделять борьбе с вирусом, а не с миграцией. Некую собственную мини-программу действий предложила лишь «Альтернатива для Германии», но и она не отличается оригинальностью.

Другой британский исследователь Д. Халикиопулу отмечает, что популисты, «работающие» на эмоциональной риторике, сейчас потеряют свою привлекательность, так как в условиях пандемии избиратели предпочтут хладнокровную компетентность и экспертные мнения ${ }^{6}$. Директор программы изучения общества, культуры и политики Университета Джона Хопкинса Э. Лангенбахер считает, что протестное голосование за популистские партии - это своего рода «роскошь», которую избиратели не смогут себе позволить в условиях кризисного и посткризисного реагирования ${ }^{7}$.

Однако данные прогнозы краткосрочны, и указанные тренды - отражение момента. Можно предположить, что после преодоления пандемии популизм найдёт способ реабилитироваться, в том числе, приписав себе часть заслуг партий мейнстрима (в том, что касается закрытия границ и других ограничений). Очевидны катастрофические последствия пандемии для мировой экономики: множество людей и домашних хозяйств либо потеряют стабильный доход, либо долго будут восстанавливать его после вынужденной остановки бизнеса. И часть оказавшихся в сложной ситуации избирателей окажется восприимчива к упрощённым решениям и эмоциональной риторике, которые вновь предложат им популисты. Д.А. Пареньков справедливо замечает, что в условиях масштабных кризисов растет спрос на «консервативные

\footnotetext{
${ }^{5}$ Smith A. Coronavirus used by European populist right to challenge E.U. open borders. NBC News, 07.03.2020. URL: https://www.nbcnews.com/news/world/coronavirus-used-european-populist-right-challengee-u-open-borders-n1149491 (дата обращения: 09.04.2020).

${ }^{6}$ Halikiopoulou D. The pandemic is exposing the weaknesses of populism, but also fueling authoritarianism. The London School of Economics and Political Science, 01.04.2020. URL: https://blogs.lse.ac.uk/brexit/2020/04/01/covid-19-is-exposing-the-weaknesses-of-populism/ дата обращения: 09.04.2020).

7 Langenbacher E. Has the Coronavirus Pandemic Broken the Populist Fever? American Institute for Contemporary German Studies, 26.03.2020. URL: https://www.aicgs.org/2020/03/has-the-coronaviruspandemic-broken-the-populist-fever/ (дата обращения: 09.04.2020).
} 
ценности» ${ }^{8}$, а большая часть правопопулистских партий ЕC провозглашают себя именно оплотом здравого консерватизма.

\title{
Выводы
}

Перед лицом нового глобального кризиса, в этот раз биологического происхождения, правый популизм демонстрирует два (ожидаемых) тренда. С одной стороны, он стремится использовать ситуацию в своих интересах - критикуя действия правительств, указывая на кризисное подтверждение того, о чём они уже давно говорили (необходимость закрытия границ, ограничение миграции, приоритет суверенных прав национальных государств, биополитическая риторика), присваивая себе дополнительные полномочия (в случае «популизма власти»). С другой, пока им не удалось показать себя «спасителями наций», переориентировать риторику на новые вызовы, предложить эффективную альтернативу действиям партий мейнстрима.

Но говорить о том, что вирус «убьёт» популизм, не стоит: запрос на «экспертное правление» краткосрочен, и часть избирателей, понёсших существенные экономические потери, не останется глуха к простым решениям, которые им предложат популисты. Так что европейский популизм не стоит списывать со счетов - в каком-то смысле, корона ему даже к лицу.

Проблемы функционирования политических систем европейских стран и различных идеологических семей в условиях мирового кризиса, безусловно, представляют интерес и для российских исследователей и государственных органов - с точки зрения понимания специфики европейского политического процесса, прогнозирования дальнейшего развития ситуации в странах ЕС и экстраполяции европейских реалий на российские условия.

\begin{abstract}
The COVID-19 pandemic poses a serious challenge not only for the public health and economy in the EU, but also for the political field. Different political forces try to coin their own behavioral strategies in the pandemic situation. The success of those strategies will depend on further development of the crisis. The author analyzes the effect and possible consequences of the coronavirus spread in the world for right-wing populist parties of the European Union. The author attempts to answer whether populism may benefit from the situation, pass a crash test in crisis situation and regain power prior to regular national elections.
\end{abstract}

Key words: populism, coronavirus, nationalism, biopolitics, migration.

\footnotetext{
${ }^{8}$ Пареньков Д. Коронавирус повышает запрос на консервативные ценности. Актуальный комментарий, 18.03.2020. URL: http://actualcomment.ru/koronavirus-povyshaet-zapros-na-konservativnye-tsennosti2003181444.html (дата обращения: 09.04.2020).
} 
Дата выпуска: 10 апреля 2020 года.

Материал доступен для скачивания по адресу: www.instituteofeurope.ru/publications/analytics 